\title{
Recording of Circuit Television (CCTV) as Evidence in The Process of Evidence on Criminal Case in Indonesia
}

\author{
H. Khanafi ${ }^{1}$ and Sri Endah Wahyuningsih ${ }^{2}$
}

\begin{abstract}
Proof is the most decisive stage of the proceedings, considering at this stage will be determined whether or not proved the defendant committed a criminal act as indicted prosecutors. The issues in this thesis is whether the CCTV recording can be used as evidence in the process of proving a criminal case in Indonesia and what obstacles and solutions if CCTV be used as evidence in the process of proving a criminal case. The approach used problem is empirical juridical approach. The data used are primary data, secondary data and data tertiary. While the method of data collection was done by using literature study and field work and data analysis in this research is a descriptive qualitative. The results of research and discussion addressing that (1) a video of CCTV can be used as a valid legal evidence that they meet the requirements stipulated in the ITE Law Article 5 of Act No. 19 of 2016. (2) barriers CCTV as evidence in criminal cases is the lack of lighting and lack of ITE experts from the big city, so the result is dark and the image quality is less clear, but the CCTV still can be used as electronic evidence for CCTV still in the original form. CCTV evidence greatly assist the police to carry out investigations in criminal cases of theft and murder. Suggestions in this study were: Investigator should report the crime to the local Court-related issues CCTV recording to be used as evidence.

Keywords: Closed Circuit Television (CCTV); Evidence; Criminal Law.
\end{abstract}

\section{Introduction}

Along with the development of information technology to transform the world into a digital world, the more often popping cases that involve electronic evidence for the purposes of verification.

Evidence relatively new in the world Indonesian justice is certainly in question the strength of the proof, because Indonesia does not have specific rules governing electronic documents as valid evidence received in court. To be accepted as a valid legal evidence would need to meet the formal and material requirements as set out in the ITE Law. In many cases, the necessary digital forensics and expert testimony to explain the originality and integrity of electronic evidence. Proof of whether or not the accused committed the act charged, is an essential part of criminal procedural law. ${ }^{3}$

No criminal case if it is known there is a criminal act or criminal event or crime committed, so that the examination of a criminal case in a judicial process is essentially aimed at seeking the truth material (material ewaarheid) against the case. It can be seen from the various businesses is passed by law enforcement officials in obtaining evidencerealneeded to unravel a case, both at the stage of preliminary investigation as

\footnotetext{
${ }^{1}$ Student Masters (S-2) of Law Faculty of Law UNISSULA Semarang email khanafihaji@gmail.com

${ }^{2}$ Lecturer of Faculty of Law

${ }^{3}$ Nikolas Simanjuntak Acara Pidana Indonesia Dalam Sirkus Hukum Bogor: Ghalia Indonesia 2009.
} 
the investigation and prosecution as well as at the stage of court proceedings. ${ }^{4}$ As examples of criminal cases with evidence in the murder case of cyanide coffee through CCTV.

In order to do proper investigation of the evidence information and electronic transactions, up to a crime can be revealed, it is necessary to the positive side of the progress of IT in the computer field. In other words, the application of computer science and technology can be used to examine and analyze any digital evidence with each other, so that the criminal case into the light, where offenders can be tracked, then captured to be held accountable for his crimes. The application is known as digital forensics. ${ }^{5}$

So with respect to the above description, the author intends to examine more deeply about whether the CCTV recording can be used as evidence in the process of proving a criminal case in Indonesia? And what are the barriers and solutions if CCTV be used as evidence in a criminal case verification process ?. Furthermore, the authors pour into a thesis with the title " Recording Of Circuit Television (CCTV) As Evidence In The Process Of Evidence On Criminal Case In Indonesia".

\section{Result and Discussion}

\subsection{CCTV recording as evidence in a criminal case in Indonesia}

Proof of an evidence in the form of electronic data also concerning aspects of the validity of which was used as electronic evidence has special characteristics compared evidence of non-electronic, special characteristics such as the shape stored in the electronic media, in addition to electronic evidence can be easily engineered so often doubtful validity.

An electronic archive, the minimum can include: ${ }^{6}$

- The validity of the substance of the information is determined by the processing of the information and the legal identity of the parties (legal identity).

- Format formations will be determined by the interests of the parties and / or in accordance with the context of communication that happens, especially to whom it is addressed.

- The responsibilities of the parties, both as a transmitter of information (originators) and receiver / destination information (recipient), real-code influenced by the prevailing legal norms, both ethically and by legislation.

- The validity of the information as output, technically and legally should be determined by the validity of the information and communication systems that exist.

In the law of criminal evidence in Indonesia legally not accommodate documents or information in electronic form as evidence in a court dispute resolution. In the past the evidence is inadmissible in court is limited to the evidence that was material, that

\footnotetext{
${ }^{4}$ Mohammad Taufik Makarao Hukum Acara Pidana Dalam Teori dan Praktek Bogor: Ghalia Indonesia 2004.

${ }^{5}$ Muhammad Nuh Al-Azhar Digital Forensic Panduan Praktis Investigasi Komputer Salemba Infotek Jakarta 2012.

${ }^{6}$ Edmon Makarim 2004 Kompilasi Hukum Telematika Jakarta Raja Grapindo Persada p.211
} 
is the evidence that can be seen and touched. In the context of Indonesian law, which allowed evidence in criminal stipulated in article 184 of the Criminal Procedure Code that statements of witnesses, expert testimony, letters, instructions, and the testimony of the defendant. In writing the entire evidence mentioned in the Criminal Procedure Code does not accommodate electronic evidence.

Of the five kinds of evidence which are recognized in the Criminal Procedure Code under Section 184 Criminal Procedure Code, the statements of witnesses, expert testimony, letters, instructions, and information from the defendant, it is included in a group e-mail Which is it ?.

When viewed from the five kinds of evidence in Article 184 Criminal Procedure Code, electronic mail can only be entered in the category of documentary evidence. Electronic mail or electronic document was actually the writing showcased in electronic form. Under the draft, the provision of electronic mail is not set. In fact, the definition of the letters in the general provisions of the Criminal Code is not specified, to determine whether the electronic mail into the category of documentary evidence is not an easy thing.

Indonesian Criminal Procedure Code verification system adopted under the legislation negatively (Negatief Wettlijke Bewijs Theorie), where the judge may only convict the accused if the evidence is limited manner prescribed by law and supported by the judge's conviction of the existence of tools- that evidence. Judges are not allowed to use evidence other than legally regulated by law. In the process of evidence in the trial, evidence is not necessary electronic mail original form (soft copy), it takes only prints (print out).

It refers to Article 5 (1) of the Act No.11 of 2008. Regarding the authenticity of the print (print out) electronic mail, the judge will ask the defendant or the victim of the electronic mail is there a difference from its original form? if the defendant or the victim acknowledges that electronic mail is the same as the original or not there are differences in the electronic mail fulfills the authenticity as evidence and be valid evidence.

If one party does not admit it, it is necessary statements of experts to determine whether it printouts of electronic mail, and the statements of experts that will be the basis of consideration of the judge in determining grappled printout (printout) electronic mail as evidence in the trial.

So that Article 5 of Act No. 19 Of 2016 on Information and Electronic Transactions (ITE Law) confirms that electronic information and electronic documents and printouts constitute legal evidence that is lawful and is an extension of legal evidence that is lawful in accordance with the procedural law apply in Indonesia. To be accepted as a valid legal evidence would need to meet the requirements of the formal and material requirements as stipulated in the ITE Law. In many cases, the necessary digital forensics and expert testimony to explain, among other things originality and integrity of electronic evidence.

Therefore, the video can be used as a valid legal evidence that they meet the requirements stipulated in the ITE Law. 
Pursuant to Article 5 paragraph 1 of Act No. 11 of 2008 on Information and Electronic Transaction, stating that: "Electronic Information and / or Electronic Document and / or prints with a valid legal evidence".

Elucidation of Article 5 paragraph 1 of Act No. 11 of 2008 on Information and Electronic Transactions states that electronic information and / or electronic documents constitute legal evidence that is lawful, under Article 5 paragraph 1 of Act No. 11 of 2008 on Information and Electronic Transactions above, the use of electronic systems in particular CCTV recording can be used as legal evidence in judicial proceedings as a means of evidence.

Furthermore, under Article 5 Point 2 of Act No. 11 of 2008 on Information and Electronic Transaction, stating that: "Electronic Information and / or Electronic Document and / or printout referred to in subsection (1) is an extension of legal evidence in accordance with the Law of Procedure applicable in Indonesia ".

Explanation of Figures 2 article 5 of Act No. 11 of 2008 on Information and Electronic Transaction has clearly stated that the Electronic Information and / or Electronic Document and / or the printout is an extension of the valid evidence in accordance with the Law of Procedure applicable in Indonesia.

The results of the use of electronic systems, particularly the CCTV recording can be used as legal evidence under the law applicable in Indonesia.

Referred to expansion here should be linked to the type of evidence set out in Article 5 (1) of the ITE. The expansion here means: ${ }^{7}$

- Adding to the evidence that was stipulated in the criminal procedural law in Indonesia, for example, the Criminal Procedure Code. Electronic Information and / or Electronic Records as Evidence Electronic increase the types of evidence set out in the Criminal Procedure Code.

- Widening the scope of the evidence that was stipulated in the criminal procedural law in Indonesia, for example in the Criminal Code. Printouts of electronic documents is information or documentary evidence set out in the Criminal Code.

Expansion of the evidence set out in the Criminal Code is already regulated in various laws are scattered. For example, legislation Company Documents, legislation Terrorism, Anti-Corruption laws, laws on Money Laundering. ITE Act confirms that the entire law applicable in Indonesia, Information and Electronic Documents and printouts can be used as a valid legal evidence. As proposed by Edmon Makarim that the existence of electronic evidence as valid evidence and stand alone should ensure that records or data, run in accordance with applicable regulations.

\subsection{Obstacles and solutions CCTV used as evidence in the process of proving a criminal case.}

So that the investigation can be done right on the evidence of information and electronic transactions, so that a crime can be revealed, it is necessary to the positive side of progress in the field of computers. This means the application of science and computer technology to examine and analyze any digital evidence with each other, so that these crimes can be revealed and where the perpetrators can be tracked, then

${ }^{7}$ Sitompul Josua, Cyberspace Cybercrime Cyberlaw PT.Tatanusa Jakarta 2012 
captured to be held accountable for his crimes. The application is known as digital forensics. ${ }^{8}$

According to Muhammad Nuh Al-Azhar, the classification of digital forensic or digital forensic specialties that have a broad scope, classification based on the physical and logical forms of evidence are examined and analyzed as follows: ${ }^{9}$

- Computer Forensic. This relates to forensic examination and analysis of electronic evidence in the form of a personal computer (Personal Computer-PC), laptop or notebook, netbook and tablet. Examination of the type of evidence is usually associated with recovery files.

- Mobile Forensic. This forensic evidence related to the type of electronic goods such as mobile (HP) and smartphones. This examination is usually associated with digital information stored that evidence.

- Audio Forensic. Forensics is associated with a sound recording perpetrators. Recordings are usually checked for the benefit of voice recognition.

- Video Forensic. This relates to forensic evidence such as video footage usually comes from CCTV (Closed Circuit Television). CCTV recording is examined relating to the activities of criminals, who was captured on the camera. These recordings are then analyzed to take a screenshot of the perpetrator's face or license plate number of the vehicle the suspect. Issues relating to the CCTV recording is lower video resolution and camera quality is not good, so when this CCTV recordings were analyzed, the results are not optimal. In addition to the resolution of the problem, there are other factors that influence whether or not the maximum magnification of objects and levels of illumination around the object.

- Image Forensic. This forensic evidence related to the type of digital form of digital image files were examined and analyzed to determine the digital camera equipment used to take the picture.

- Cyber Forensic. This relates to forensic examination and analysis of the cases related to the Internet or a network such as a LAN (local area network). ${ }^{10}$

Based on the results of research by the author related to problems in this thesis, it is known that CCTV barriers as evidence in a criminal case that the process of proving the lack of lighting and lack of experts EIT from the big city, so the result is dark and the image quality is less clear, but the CCTV still can be used as electronic evidence for CCTV still in the original form.

\section{Closing}

\subsection{Conclusion}

After a discussion of the data obtained in the study, the authors conclude that CCTV can be used as evidence as long as they meet the requirements set in the ITE Law Article 5 of Act No. 19 of 2016.

\footnotetext{
${ }^{8}$ Ibid 32012.

${ }^{9}$ Ibid.

${ }^{10}$ Nugraha Irman " Pembuktian Alat Informasi dan Transaksi Elektronik Dalam Pembobolan ATM" Thesis Faculty of Law Jendral Sudirman University Purwokerto 2013.
} 
Some obstacles can occur, both technically CCTV itself or operationally, but it does not interfere with the course of the investigation and the successful theft or murder suspects face justice for such crimes, because CCTV is an original evidence.

\subsection{Suggestion}

That the author gives suggestions for the smooth enforcement, namely:

- Victims of crime should be as soon as possible to report the incident to the nearest police CCTV recording that can be used by the investigator and the investigator can report these records to the Chairman of the Court.

- The police should cooperate with people who have a CCTV recording a criminal offense to immediately report the incident to the police. CCTV has a term for storing recordings CCTV, therefore every person who has CCTV and have CCTV recording that records an incident a criminal offense should be stored or moved the CCTV recording to a memory card or thumb drive.

- The government and police cooperated to install CCTV on every corner areas or areas that are prone to crime and CCTV recordings should be connected to the police and the police monitored on an ongoing basis.

\section{Bibliography}

[1] Edmon Makarim 2004 Kompilasi Hukum Telematika Jakarta Raja Grapindo Persada

[2] Mohammad Taufik Makarao 2004 Hukum Acara Pidana Dalam Teori dan Praktek Bogor: Ghalia Indonesia

[3] Muhammad Nuh Al-Azhar 2012 Digital Forensic Panduan Praktis Investigasi Komputer Salemba Infotek Jakarta

[4] Nikolas Simanjuntak 2009 Acara Pidana Indonesia Dalam Sirkus Hukum Bogor: Ghalia Indonesia

[5] Nugraha Irman 2013 "Pembuktian Alat Informasi dan Transaksi Elektronik Dalam Pembobolan ATM" Skripsi Fakultas Hukum Universitas Jendral Soedirman Purwokerto.

[6] Sitompul Josua 2012 Cyberspace Cybercrime Cyberlaw Tatanusa Jakarta.

[7] Act No. 11 Of 2008 on Information and Electronic Transactions 